\title{
Phylogenetic analysis of the sharpshooter genus Subrasaca Young, 1977 (Hemiptera, Cicadellidae, Cicadellini)
}

\author{
Roberta dos Santos da Silva ${ }^{1,3}$, Gabriel Mejdalani', Rodney R. Cavichioli ${ }^{2}$ \\ I Departamento de Entomologia, Museu Nacional, Universidade Federal do Rio de Janeiro, Quinta da Boa \\ Vista, São Cristóvão, 20940-040, Rio de Janeiro, RJ, Brasil 2 Departamento de Zoologia, Setor de Ciências \\ Biológicas, Universidade Federal do Paraná, Caixa Postal 19020, 81531-980, Curitiba, PR, Brasil 3 Pós- \\ graduação em Zoologia, Museu Nacional, Universidade Federal do Rio de Janeiro
}

Corresponding author: Gabriel Mejdalani (mejdalan@acd.ufrj.br)

Academic editor: Mick Webb | Received 16 January 2015 | Accepted 16 February 2015 | Published 27 February 2015

http://zoobank.org/79073B20-2C28-46E9-833F-5136AEBCD93F

Citation: Silva RS, Mejdalani G, Cavichioli RR (2015) Phylogenetic analysis of the sharpshooter genus Subrasaca Young, 1977 (Hemiptera, Cicadellidae, Cicadellini). ZooKeys 484: 53-70. doi: 10.3897/zookeys.484.9264

\begin{abstract}
The South American sharpshooter genus Subrasaca comprises 14 species. Some species of this genus are quite common in the Brazilian Atlantic Rainforest. In this paper, a phylogenetic analysis of Subrasaca, based on a matrix of 20 terminal taxa and 72 morphological characters of the head, thorax, and male and female genitalia, is presented. The analysis yielded six equally most parsimonious trees (197 steps, $\mathrm{CI}=0.6091, \mathrm{RI}=0.5722$, and $\mathrm{RC}=0.3486$ ). The results suggest that Subrasaca is a monophyletic taxon, although the genus branch is not robust. The clade showing the highest bootstrap and Bremer scores is formed by species with longitudinal dark brown to black stripes on the forewings (S. bimaculata, S. constricta, S. curvovittata, and S. flavolineata), followed by S. atronasa + S. austera.
\end{abstract}

\section{Keywords}

Auchenorrhyncha, Cicadellinae, cladistics, Membracoidea, phylogeny 


\section{Introduction}

The infraorder Cicadomorpha comprises three superfamilies, Cicadoidea (cicadas), Cercopoidea (spittlebugs or froghoppers), and Membracoidea (leafhoppers and treehoppers). According to Hamilton (1999), the monophyly of the Cicadomorpha is well-supported by morphological synapomorphies, including the presence of a complex filter chamber. Cryan (2005), based on molecular data (18S rDNA, $28 \mathrm{~S}$ rDNA, and histone 3), also supports the monophyly of the Cicadomorpha and suggests the following relationships for the superfamilies: (Membracoidea (Cicadoidea, Cercopoidea)). Based both on morphological and molecular data, the monophyly of the Membracoidea is also well-supported (Evans 1963, Dietrich and Deitz 1993, Hamilton 1999, Cryan 2005). Synapomorphies of the Membracoidea include the enlarged, transverse metathoracic coxae and a pair of rod-shaped lateral apodemes associated with the scutellar suture (Dietrich and Deitz 1993).

The family Cicadellidae (leafhoppers), with over 21,000 described species placed in more than 120 family-group taxa (Oman et al. 1990, Hamilton 1999), includes many species of economic importance because they are vectors of pathogens of cultivated plants (Nielson 1985). According to the morphological phylogeny of Hamilton (1983) and the molecular phylogeny (28S rDNA) of Dietrich et al. (2001), Cicadellidae is a paraphyletic group because treehoppers (Aetalionidae and Membracidae) are derived from leafhoppers. Taxonomically, cicadellids can be distinguished from other membracoids by the mesanepisternum without a hooklike process, separated from the katepisternum by a suture, and hind tibia with setae of longitudinal rows usually large and conspicuous (Dietrich 2005). With over 2,000 known species and a cosmopolitan distribution, Cicadellinae (sharpshooters) is the third largest subfamily of the Cicadellidae (Mejdalani 1998, Takiya 2007, McKamey 2007). According to Young $(1968,1977,1986)$, this subfamily is divided into two tribes, a cosmopolitan Cicadellini and a New World Proconiini. Sharpshooters feed on the low-nutrient xylem sap of vascular plants. Some species of this group are important vectors of xylem-borne phytopathogenic bacteria (Redak et al. 2004).

The genus Subrasaca Young, 1977 belongs to the Cicadellini. Subrasaca has records from Brazil and Argentina, as well as dubious records of $S$. monacha from Colombia (Young 1977, McKamey 2007, Silva et al. 2013b). Species records are mostly from the Atlantic Rainforest. Subrasaca comprises currently 14 species (Silva et al. 2013a,b): S. atronasa Young, 1977, S. austera Young, 1977, S. bimaculata Silva, Cavichioli \& Mejdalani, 2013a, S. constricta Silva, Cavichioli \& Mejdalani, 2013a, S. curvovittata (Stål, 1862), S. diminuta Silva, Cavichioli \& Mejdalani, 2013b, S. flavolineata (Signoret, 1855), S. flavoornata (Stål, 1862), S. ignicolor (Signoret, 1854) (type species), S. monacha (Melichar, 1951), S. nigriventris (Signoret, 1855), S. rachelae Silva, Cavichioli \& Mejdalani, 2013b, S. rhienetta (Signoret, 1854), and S. rubra Silva, Cavichioli \& Mejdalani, 2013 b.

Taxonomically, Subrasaca differs from other genera of the Cicadellini by the following combination of male genital characteristics (Silva et al. 2013b): (1) aedeagus usually short and dorsally expanded; (2) styles (parameres) with distinct preapical lobe; (3) paraphyses with two or four rami (except in S. monacha, with only one ramus); and 
(4) subgenital plates connected to each other at base by a triangular membranous area, not extending posteriorly as far as pygofer apex. Subrasaca species are generally quite colorful and range in length from 4.8 to $7.7 \mathrm{~mm}$. Young (1977: 445), based on overall similarity, included Subrasaca in his Juliaca group of genera, which also includes Juliaca Melichar, 1926, Mesogonia Melichar, 1926, Rotigonalia Young, 1977, Geitogonalia Young, 1977, Plerogonalia Young, 1977, Scopogonalia Young, 1977, Cyclogonia Melichar, 1926, Beirneola Young, 1977, and Fusigonalia Young, 1977.

Here we use morphological data of the head, thorax, male and female genitalia to investigate the phylogenetic relationships among the species of Subrasaca. Among our outgroups, we included four genera of the Juliaca group (Cyclogonia, Juliaca, Geitogonalia, and Scopogonalia).

\section{Material and methods}

\section{Specimens for the study}

Specimens of 12 of the 14 described species of Subrasaca were studied (S. atronasa and S. monacha were not obtained and thus coded based on Young 1977 and Wilson et al. 2009). The matrix includes 20 terminal taxa (14 Subrasaca species and six outgroups). The outgroups are four representatives of the Juliaca generic group [Cyclogonia caeliguttata Mejdalani \& Nessimian, 1991, Juliaca sp., Geitogonalia quatuordecimmaculata (Taschenberg, 1884), Scopogonalia subolivacea (Stål, 1862)], Versigonalia ruficauda (Walker, 1851), and a member of the Proconiini, Tretogonia cribrata Melichar, 1926, which was employed for rooting the trees.

The studied specimens belong to the following institutions: Departamento de Entomologia, Museu Nacional, Universidade Federal do Rio de Janeiro (MNRJ, Rio de Janeiro); Coleção Entomológica Prof. José Alfredo P. Dutra, Departamento de Zoologia, Instituto de Biologia, Universidade Federal do Rio de Janeiro (DZRJ, Rio de Janeiro); and Coleção de Entomologia Pe. Jesus S. Moure, Departamento de Zoologia, Setor de Ciências Biológicas, Universidade Federal do Paraná (DZUP, Curitiba). The number of specimens examined of each terminal taxon, their geographical distribution, and collections are listed in Table 1.

\section{Techniques for preparation of specimens and terminology}

The techniques for preparation of male and female genital structures follow Oman (1949) and Mejdalani (1998), respectively. The dissected parts are stored in small vials with glycerin, as suggested by Young and Beirne (1958). The first and second pair of valvulae of the ovipositor were mounted on temporary slides with glycerin. The descriptive terminology adopted herein follows mainly Young (1977), except for the facial areas of the head (Hamilton 1981, Mejdalani 1993, 1998) and the female genitalia (Nielson 1965, Hill 1970). 
Table I. Taxa included in the phylogenetic analysis of Subrasaca (in bold) and outgroups. The number of females and males examined, their distribution (Brazilian states), and collections are provided for each taxon.

\begin{tabular}{|c|c|c|c|c|}
\hline Taxon & Females & Males & Distribution & Collection \\
\hline $\begin{array}{l}\text { Cyclogonia caeliguttata Mejdalani \& } \\
\text { Nessimian, } 1991\end{array}$ & 2 & 2 & RJ & MNRJ \\
\hline Juliaca sp. & 2 & 2 & RJ & MNRJ \\
\hline $\begin{array}{l}\text { Geitogonalia quatuordecimmaculata } \\
\text { (Taschenberg, 1884) }\end{array}$ & 2 & 2 & RJ & MNRJ \\
\hline Scopogonalia subolivacea (Stål, 1862) & 2 & 2 & RJ, MG & MNRJ \\
\hline Versigonalia ruficauda (Walker, 1851) & 2 & 2 & $\mathrm{RJ}$ & MNRJ \\
\hline Tretogonia cribrata Melichar, 1926* & 2 & 2 & RJ & MNRJ \\
\hline S. atronasa Young, $1977^{* *}$ & - & - & - & - \\
\hline S. austera Young, 1977 & 2 & 1 & SC & DZUP \\
\hline S. bimaculata Silva et al., 2013 & 19 & 26 & MG, SP, PR & DZRJ, DZUP, MNRJ \\
\hline S. constricta Silva et al., 2013 & 2 & 3 & BA & DZUP, MNRJ \\
\hline S. curvovittata (Stål, 1862) & 11 & 6 & RJ & DZRJ, DZUP, MNRJ \\
\hline S. diminuta Silva et al., 2013 & 8 & 6 & SP, PR & DZUP, MNRJ \\
\hline S. flavolineata (Signoret, 1855) & 9 & 15 & RJ & DZRJ, DZUP, MNRJ \\
\hline S. flavoornata (Stål, 1862) & 6 & 2 & RJ & MNRJ \\
\hline S. ignicolor (Signoret, 1854) & 22 & 14 & RJ, SP & MNRJ \\
\hline S. monacha (Melichar, 1951)** & - & - & - & - \\
\hline S. nigriventris (Signoret, 1855) & 10 & 10 & $\mathrm{RJ}$ & MNRJ \\
\hline S. rachelae Silva et al., 2013 & 19 & 12 & ES & DZRJ, DZUP, MNRJ \\
\hline S. rbienetta (Signoret, 1854) & 3 & 3 & RJ, SP & MNRJ \\
\hline S. rubra Silva et al., 2013 & 7 & 10 & MG, RJ, SP & DZRJ, DZUP, MNRJ \\
\hline
\end{tabular}

Brazilian states: BA - Bahia; ES - Espírito Santo; MG - Minas Gerais; PR - Paraná; RJ - Rio de Janeiro; SC - Santa Catarina; SP - São Paulo. DZRJ - Departamento de Zoologia, Universidade Federal do Rio de Janeiro; DZUP - Departamento de Zoologia, Universidade Federal do Paraná; MNRJ - Museu Nacional, Universidade Federal do Rio de Janeiro; ${ }^{*}$ root of the phylogenetic analysis; ${ }^{* *}$ coded based on Young (1977) and Wilson et al. (2009).

\section{Cladistic analysis}

Morphological characters of the head, thorax, male and female genitalia were included in the unpolarized matrix (Nixon and Carpenter 1993), which was assembled using the Nexus Data Editor (Page 2001). Hypotheses of primary homology were proposed based on the topological identity of the structures (Pinna 1991). All characters were initially scored equal weights. Character states were scored as underscores (_) when inapplicable or as question marks (?) when unavailable. The heuristic search algorithm, as implemented in PAUP* 4.0 (Swofford 2002), was employed for searching the most parsimonious trees. The successive weighting procedure (Carpenter 1988, 1994) was based on the maximum rescaled consistency index (rc) of the characters (Farris 1969, 1989). The strict consensus method was employed for all original most parsimonious trees. Clade support was estimated by computing 10.000 bootstrap replicates (Felsen- 
stein 1985) with heuristic search in PAUP* 4.0 and by decay indices (Bremer 1988, 1994) in TreeRot 3.0 (Sorenson and Franzosa 2007). Autapomorphic characters were included in the matrix, as suggested by Yeates (1992), but we provide consistency index (CI) values considering all characters as well as only the informative ones.

\section{Results and discussion}

The data matrix (Table 2) consists of 72 morphological characters, 35 of the external morphology, 25 of the male genitalia, and 12 of the female genitalia. Among these characters, 51 are binary and 21 are multistate, being 52 informative for the parsimony analysis. The characters, their states, and ci greater than 0.5 are listed below. Although many of the characters are based on color patterns, these are consistent intraspecifically in Subrasaca. Figures 1 (external morphology and male genitalia) and 2 (female genitalia) provide some examples of characters employed in the phylogenetic analysis.

\section{Morphological characters of the phylogenetic analysis}

\section{External morphology and coloration}

1. Shape of anterior margin of crown, dorsal view: (0) rounded (Fig. 1a), (1) pronounced with a triangular shape (Fig. 1c).

2. Position of ocelli on crown: (0) slightly anterior to imaginary line between anterior eye angles (Fig. 1c); (1) posterior to imaginary line between eye angles; (2) on imaginary line between eye angles.

3. Color of face: (0) black; (1) yellow; (2) light brown; (3) black with yellow central region enclosing black macula; (4) black with cream central macula and two orange maculae on anterior portion; (5) black with orange macula on posterior portion; (6) black with orange macula on anterior portion; (7) yellow with black Y-shaped macula; (8) yellow with black central portion enclosing yellow macula;

(9) cream with black central portion and anterior region with orange macula; (A) yellow with brown streaks and median stripe; (B) black with orange lateral portions; (C) yellow with small black maculae on anterior portion. $\mathrm{ci}=0.9$.

4. Macula or maculae, originated from face, limited to central portion of apex of crown: (0) absent; (1) present (Fig. 1b).

5. Color of macula or maculae, originated from face, limited to central portion of apex of crown: (0) yellow; (1) brown with yellow (Fig. 1b); (2) orange; (3) brown. ci $=1$.

6. Maculae on lateroapical portions of crown, originated from face: $(0)$ absent; (1) present (Fig. 1a). ci $=0.5$.

7. Dark brown to black transversal band on anterior portion of crown: (0) absent; (1) present (Fig. 1b). ci = 1.0. 
Table 2. Data matrix for the phylogenetic analysis of Subrasaca (in bold) and outgroup taxa. (_) codes for inapplicable states, (?) for unavailable data, (A) for state 10, (B) for 11, and (C) for 12. Outgroup genera are Cyclogonia, Juliaca, Geitogonalia, Scopogonalia, Versigonalia, and Tretogonia (root).

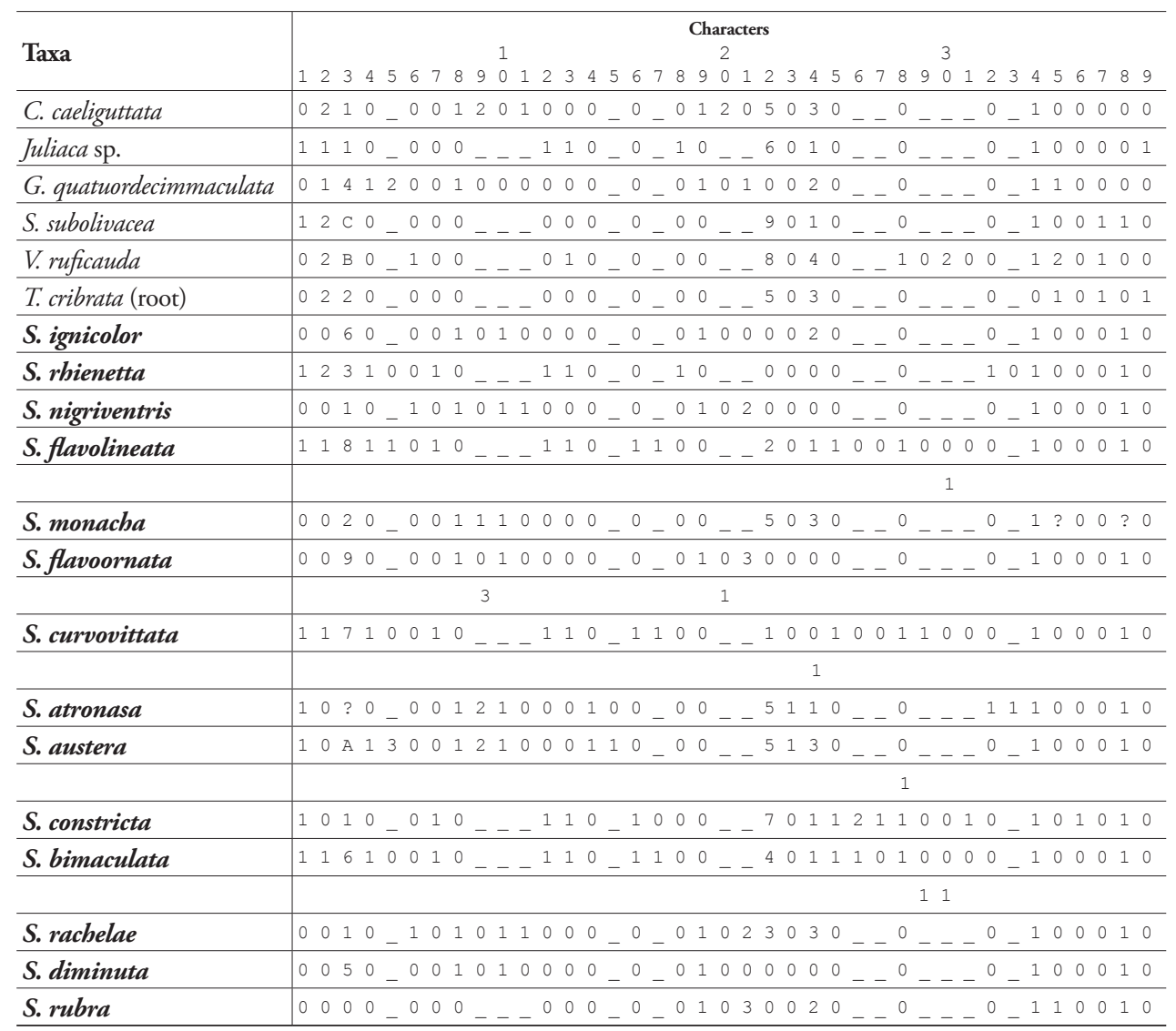

8. Transverse band on middle portion of crown: (0) absent; (1) present. ci $=0.5$.

9. Color of transverse band on middle portion of crown: (0) orange; (1) light brown; (2) whitish-yellow; (3) yellow. ci = 0.6.

10. Aspect of transverse band on middle portion of crown: (0) incomplete; (1) complete. $\mathrm{ci}=1.0$.

11. Lateral portions of median transverse band reaching posterior margin of crown: (0) absent; (1) present. ci $=0.5$.

12. Dark brown to black transverse band on posterior portion of crown: (0) absent; (1) present (Fig. 1b). ci $=0.5$.

13. Dark brown to black transverse band on anterior portion of pronotum: (0) absent; (1) present (Fig. 1b).

14. Whitish-yellow transverse band on middle portion of pronotum: (0) absent; (1) present. $\mathrm{ci}=1$. 
Table 2. Continued.

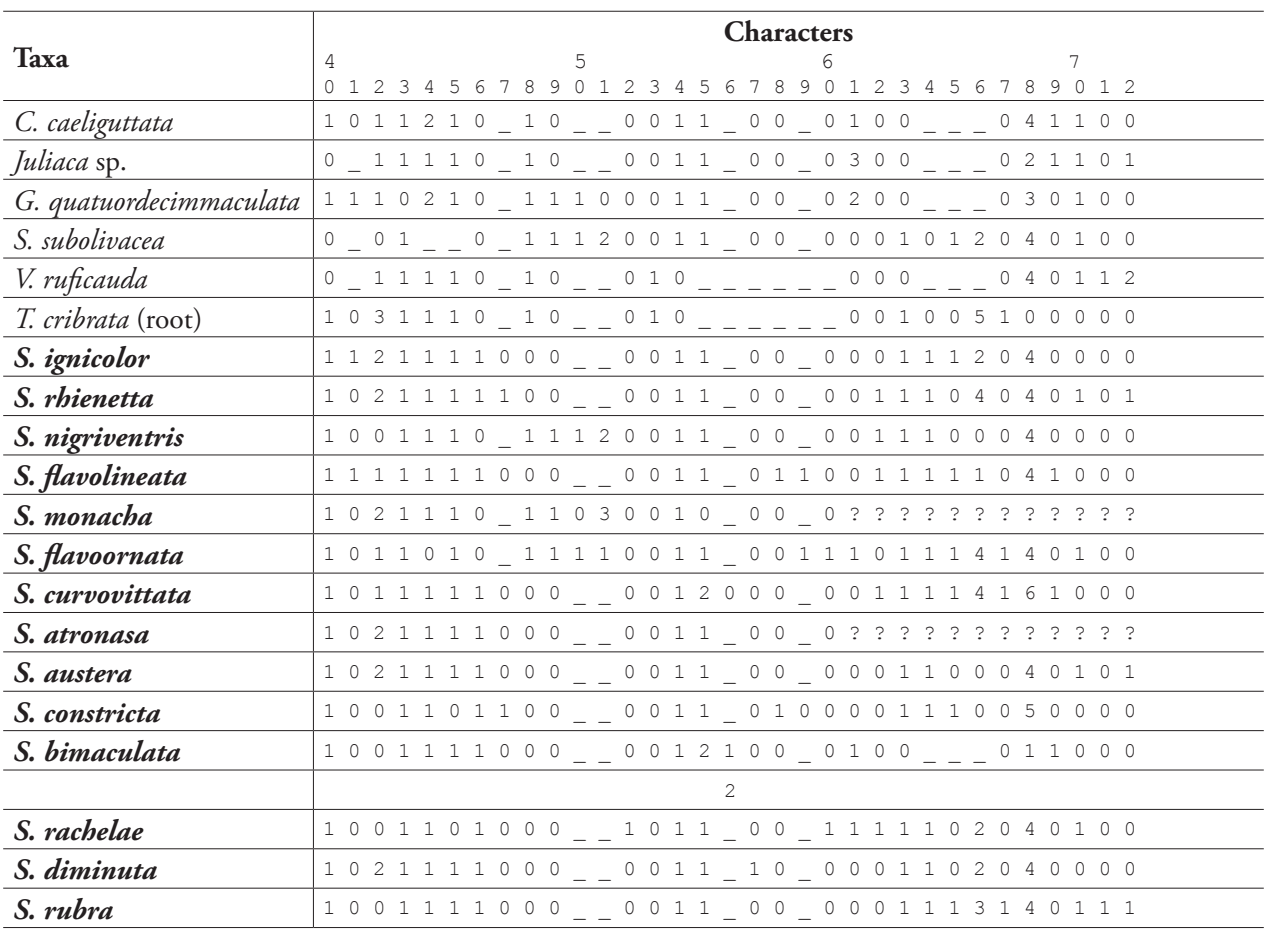

15. Band on middle portion of pronotum with strong concavity: (0) absent; (1) present. $\mathrm{ci}=1$.

16. Dark brown to black transverse band located before base of pronotum (posterior margin): (0) absent; (1) present (Fig. 1b). ci $=1$.

17. Aspect of dark brown to black transverse band located before base of pronotum (posterior margin): (0) narrow (Fig. 1c); (1) thick (Fig. 1b). ci = 1.

18. Dark brown to black transverse band at base of pronotum (posterior margin): (0) absent; (1) present. $\mathrm{ci}=0.5$.

19. Pair of maculae on central portion of pronotum: (0) absent; (1) present.

20. Color of pair of maculae on central portion of pronotum: (0) orange; (1) yellow; (2) blue. ci = 1 .

21. Position of pair of yellow or orange maculae on pronotum: (0) strongly oblique and restricted to sides of pronotum; (1) strongly oblique and reaching central portion of pronotum; (2) moderately oblique (Fig. 1a); (3) not oblique. ci = 1 .

22. Color of mesonotum: (0) entirely black; (1) black with yellow scutellum; (2) yellow with black T-shaped macula (Fig. 1b); (3) brown with brownish-yellow scutellum and two anterior maculae (Fig. 1a); (4) black with yellow scutellum and two anterior maculae; (5) light brown; (6) dark brown with yellow apex; (7) yellow (Fig. 1c); (8) black with irregular yellow maculae; (9) yellow with black maculae on lateroanterior portions. $\mathrm{ci}=0.9$. 

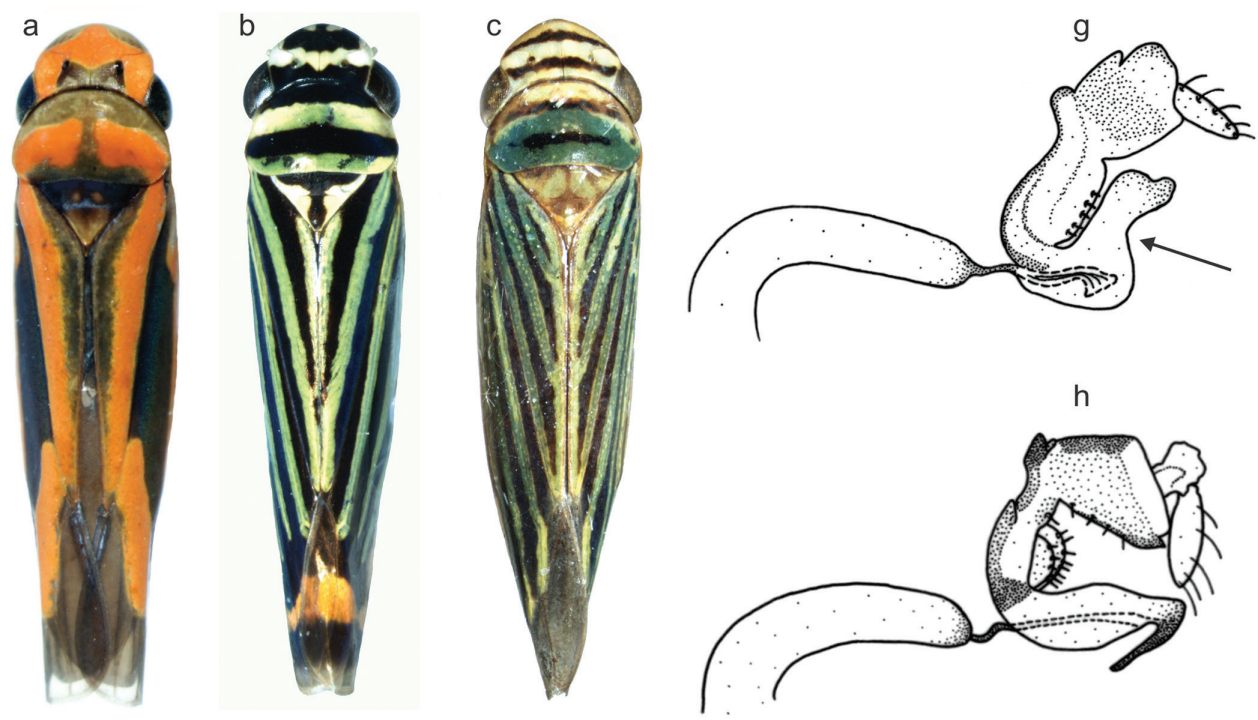

$\mathrm{h}$
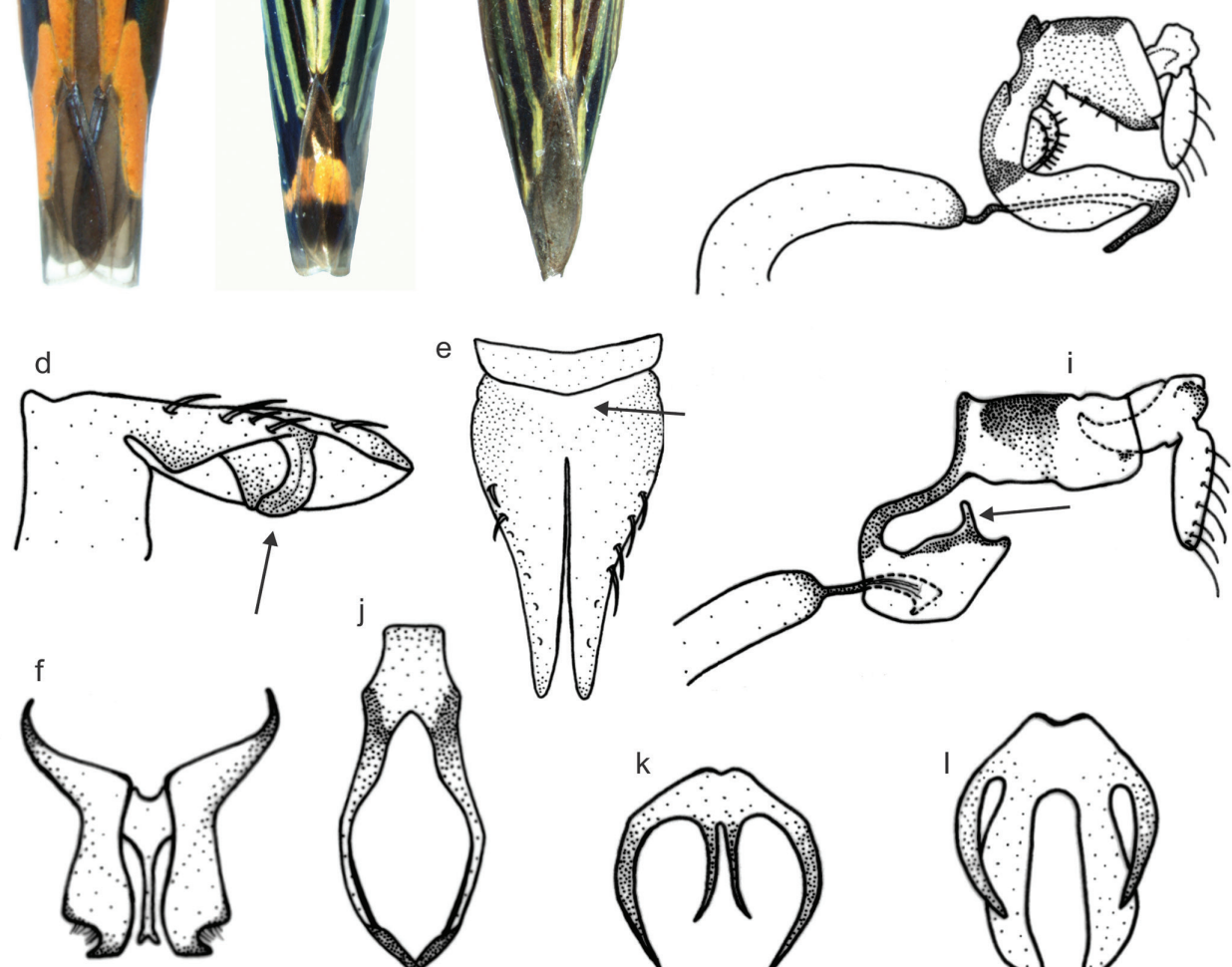

Figure I. Examples of characters for the phylogenetic analysis of Subrasaca (external morphology and male genitalia). a body of Subrasaca rachelae (length $5.3 \mathrm{~mm}$ ): rounded anterior margin of crown (character 1, state 0 ), maculae on lateroapical portions of crown (c6, s1), pair of moderately oblique maculae on pronotum (c21, s2) b $S$. flavolineata (length $5.4 \mathrm{~mm}$ ): mesonotum with T-shaped macula (c22, s2), longitudinal stripes on forewings (c25, s1) c S. constricta (length $5.7 \mathrm{~mm}$ ): pronounced anterior margin of crown (c1, s1) d pygofer lobe of $S$. constricta, dorsal view: dorsoapical process (c36, s1; arrowed) e subgenital plates of $S$. bimaculata: membranous basal area (c38, s1; arrowed) $\mathbf{f} S$. nigriventris: styles with preapical lobe $(c 40, s 1)$ and apex transversely truncate $(c 42, s 0)$, stalk of connective clearly differentiated, not extending beyond apex of styles $(\mathrm{c} 44, \mathrm{~s} 1) \mathbf{g}$ aedeagus of $S$. constricta: dorsal lobe $(\mathrm{c} 46, \mathrm{~s} 1)$ with constriction (c47, s1; arrowed) $\mathbf{h}$ aedeagus of $S$. nigriventris: shaft longer than high $(c 48, s 1)$, pair of spiniform apical processes (c51, s2) $\mathbf{i}$ aedeagus of $S$. rachelae: pair of preapical processes (c52, s1; arrowed) $\mathbf{j} S$. rubra: paraphyses with two rami $(\mathrm{c} 55, \mathrm{~s} 1) \mathbf{k} S$. curvovittata: paraphyses with four rami $(\mathrm{c} 55, \mathrm{~s} 2)$, inner rami small and narrow (c56, s0) I S. bimaculata: inner rami of paraphyses broader and larger than outer rami (c56, s1). 
23. Texture of forewings: (0) coriaceous (Fig. 1a-c); (1) translucent. $\mathrm{ci}=1$.

24. Color of basal portion of clavus, reaching apex of scutellum: (0) black; (1) yellow (Fig. 1b, c); (2) orange; (3) light brown (Fig. 1a); (4) blue.

25. Set of dark brown to black longitudinal stripes on forewings: (0) absent; (1) present (Fig. 1b, c). ci $=1$.

26. Number of dark brown to black longitudinal stripes on forewings: ( 0 ) four; (1) six; (2) eight. ci = 1 .

27. Position of longitudinal stripe on forewings: (0) not along outer edge of inner apical cell; (1) along outer edge of inner apical cell. $\mathrm{ci}=1$.

28. Transverse band on anteapical portion of forewings: (0) absent; (1) present. $\mathrm{ci}=0.5$.

29. Aspect of transverse band on anteapical portion of forewings: $(0)$ not connected to yellow longitudinal stripe; (1) connected to yellow longitudinal stripe. $\mathrm{ci}=1$.

30. Color of transverse band on anteapical portion of forewings: (0) yellow; (1) orange; (2) brown. ci $=1$.

31. Extension of transverse band on anteapical portion of forewings: (0) reaching the four anteapical cells; (1) 1/2 of the width of wing, reaching a maximum of two anteapical cells. $\mathrm{ci}=1$.

32. Transverse band of corium on region of apex of clavus: (0) absent; (1) present. $\mathrm{ci}=0.5$.

33. Color of transverse band of corium on apex of clavus: (0) yellow; (1) whitishyellow. ci $=1$.

34. Extension of hind legs at rest position: (0) not reaching posterior margin of lateral lobe of pronotum; (1) reaching posterior margin of lateral lobe of pronotum. $\mathrm{ci}=1$.

35. Color of legs: (0) yellow; (1) brown; (2) red. ci $=0.5$.

Male genitalia

36. Dorsoapical process of pygofer: (0) absent; (1) present (Fig. 1d). ci $=1$.

37. Ventroapical process of pygofer: (0) absent; (1) present. $\mathrm{ci}=0.5$.

38. Triangular membranous area uniting subgenital plates basally: $(0)$ absent; (1) present (Fig. 1e). ci $=0.5$.

39. Extension of subgenital plates in relation to pygofer: $(0)$ not extending beyond apex of pygofer; (1) extending beyond apex of pygofer. ci $=0.5$.

40. Preapical lobe of styles: (0) absent; (1) present (Fig. 1f). ci $=0.5$.

41. Styles, length of portion posterior to preapical lobe: (0) less than $1 / 3$ of style length (Fig. 1f); (1) 1/3 of style length.

42. Shape of apex of styles, dorsal view: (0) transversely truncated (Fig. 1f); (1) obliquely truncated; (2) obtuse; (3) forked.

43. Shape of connective: (0) T-shaped; (1) Y-shaped (Fig. 1f). ci = 1 . 
44. Aspect of stalk of connective: (0) very short, not clearly differentiated; (1) clearly differentiated, not extending beyond apex of styles (Fig. 1f); (2) clearly differentiated, extending beyond apex of styles. $\mathrm{ci}=1$.

45. Width of stalk of connective: (0) similar to width of base of arms; (1) narrower than base of arms (Fig. 1f). ci $=0.5$.

46. Dorsal lobe of aedeagus: (0) absent; (1) present (Fig. 1g).

47. Constriction of dorsal lobe of aedeagus: (0) absent; (1) present (Fig. 1g). ci = 0.5.

48. Length of aedeagus: (0) as long as high; (1) longer than high (Fig. 1h).

49. Apical processes of aedeagus: (0) absent; (1) present (Fig. 1h).

50. Number of apical processes of aedeagus: (0) one; (1) two. $\mathrm{ci}=1$.

51. Shape of apical processes of aedeagus: (0) pair of digitiform processes directed basally; (1) pair of small lobular processes; (2) pair of spiniform processes directed ventrally (Fig. 1h); (3) triangular projection directed ventrally. ci $=1$.

52. Pair of dorsally directed digitifom processes on preapical portion of aedeagus: (0) absent; (1) present (Fig. 1i). ci $=1$.

53. Pair of basal processes of aedeagus: (0) absent; (1) present. $\mathrm{ci}=1$.

54. Paraphyses: (0) absent; (1) present (Fig. $1 \mathrm{j}-1)$. ci $=1$.

55. Number of paraphyses rami: (0) one; (1) two (Fig. 1j); (2) four (Fig. 1k, l). ci = 0.6.

56. Aspect of inner rami of paraphyses with four rami: (0) narrower and smaller than outer rami (Fig. 1k); (1) broader and larger than outer rami (Fig. 11); (2) width and length similar to outer rami. $\mathrm{ci}=1$.

57. Spiniform process of paraphyses: (0) absent; (1) present. ci $=1$.

58. Process on median portion of rami of paraphyses: (0) absent; (1) present. ci $=0.5$.

59. Number of processes on median portion of paraphyses rami: (0) one on each ramus; (1) two on each ramus. $\mathrm{ci}=1$.

60. Apical processes of paraphyses: (0) absent; (1) present. ci $=0.5$.

Female genitalia

61. Aspect of median portion of posterior margin of sternite VII: (0) concave (Fig. 2b); (1) convex (Fig. 2a); (2) concave with dentiform projection; (3) convex with short triangular projection. $\mathrm{ci}=0.5$.

62. Distinctly sclerotized area on each side of anterior margin of sternite VII: (0) absent; (1) present.

63. Sclerites of “inner" sternite VIII: (0) absent; (1) present (Fig. 2c-e).

64. Number of sclerites of "inner" sternite VIII: (0) one; (1) two (Fig. 2c-e). ci = 1 .

65. Texture of sclerites of "inner" sternite VIII: (0) smooth (Fig. 2c); (1) punctuated (Fig. 2d, e).

66. Shape of sclerites of "inner" sternite VIII: (0) triangular; (1) somewhat quadrangular (Fig. 2e); (2) linear (Fig. 2c); (3) coniform; (4) oblique (Fig. 2d); (5) broad, narrowed posteriorly, and with apex located between bases of ovipositor valvulae I. ci $=0.7$. 

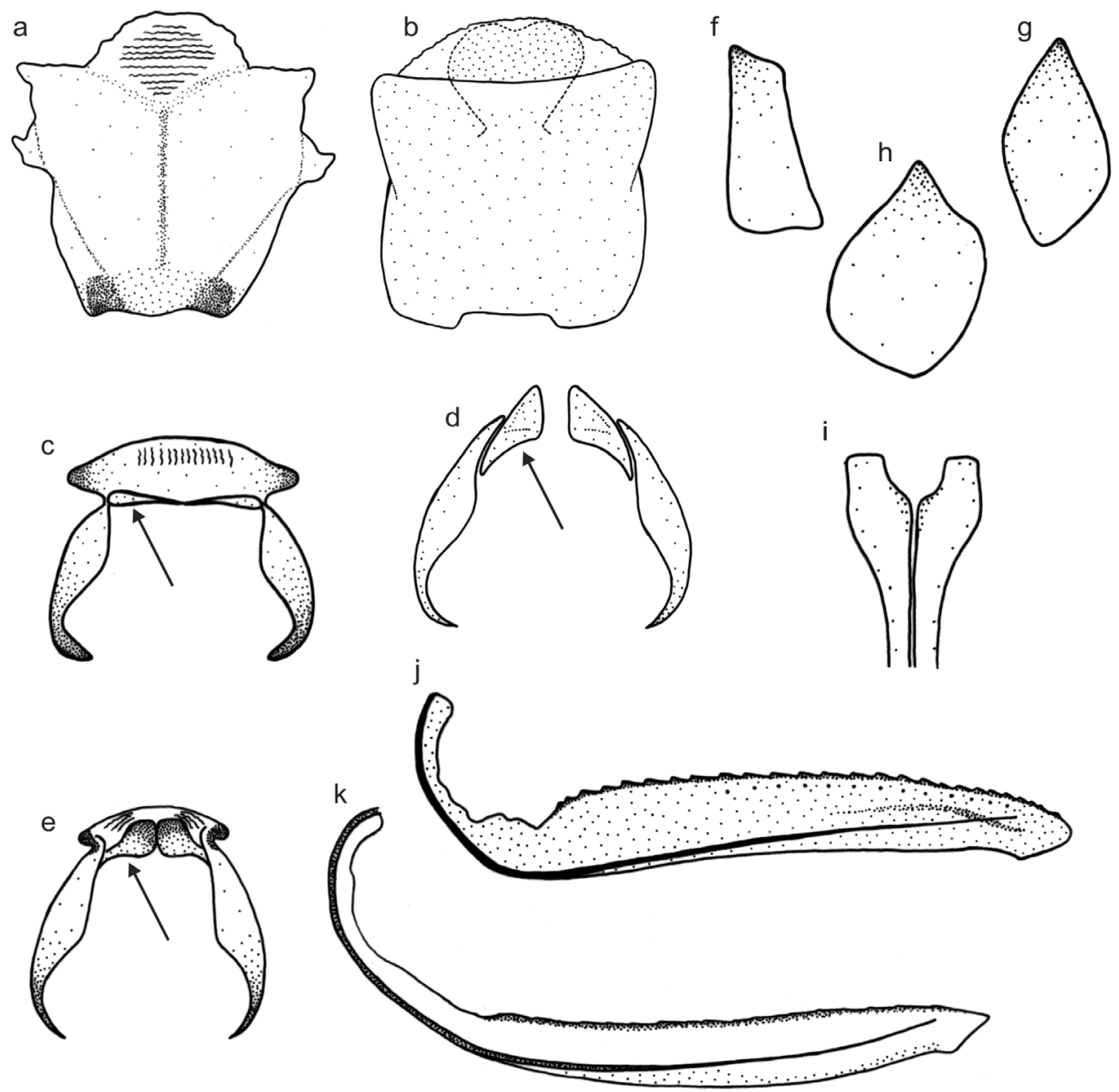

Figure 2. Examples of characters for the phylogenetic analysis of Subrasaca (female genitalia). a sternite VII of S. bimaculata: convex posterior margin at median portion (character 61, state 1) b sternite VII of S. rubra: concave posterior margin at median portion (c61, s0) c $S$. rachelae: smooth sclerites of "inner" sternite VIII (c65, s0) with linear aspect (c66, s2; arrowed) d S. flavoornata: sclerites of "inner" sternite VIII with oblique aspect (c66, s4; arrowed) e $S$. flavolineata: punctuated sclerites of "inner" sternite VIII (c65, s1; arrowed) $\mathbf{f}$ Juliaca sp.: valvifer I subrectangular $(\mathrm{c} 68, \mathrm{~s} 2) \mathbf{g} S$. diminuta: valvifer I ellipsoid (c68, s4) h $S$. curvovittata: valvifer I gutiform $(c 68, s 6)$ i $S$. rhienetta: valvulae I with expanded base (c69, s0) j S. constricta: valvula II with obtuse apex (c70, s0) and convex dorsal margin $(\mathrm{c} 72, \mathrm{~s} 0) \mathbf{k} S$. rubra: valvula II with acute apex (c70, s1), linear and indistinct teeth (c71, s1), and rectilinear dorsal margin (c72, s1).

67. Sclerites of “inner" sternite VIII directed ventrally: (0) absent; (1) present.

68. Shape of valvifers I, lateral view: (0) quadrangular; (1) trapezoidal; (2) subrectangular (Fig. 2f); (3) gutiform with lobe on distal half of dorsal margin; (4) elliptical (Fig. 2g); (5) subtriangular; (6) gutiform, posteriorly expanded (Fig. 2h). ci = 1.

69. Aspect, in ventral view, of basal portion of valvulae I of ovipositor: (0) expanded (Fig. 2i); (1) continuous, without expansion. 
70. Aspect of apex of valvulae II of ovipositor: (0) obtuse (Fig. 2j); (1) acute (Fig. 2k). 71. Shape of teeth of valvulae II of ovipositor: (0) triangular and distinct (Fig. 2j); (1) linear and indistinct (Fig. 2k). ci $=0.5$.

72. Aspect of dorsal margin of valvulae II of ovipositor: (0) convex (Fig. 2j); (1) rectilinear (Fig. 2k); (2) concave (Young 1977: Fig. 881k).

\section{Main aspects and discussion of the phylogenetic analysis}

The analysis with equal weights resulted in six most parsimonious trees with length = 197 , consistency index $(\mathrm{CI})=0.6091$ (excluding uninformative characters $=0.5389$ ), retention index $(\mathrm{RI})=0.5722$, and rescaled consistency index $(\mathrm{RC})=0.3486$. The trees differ from one another (1) in the position of $V$. ruficauda (outgroup), (2) positions of S. rubra and S. flavoornata, which appear as sister groups or not, and (3) positions of $S$. rubra, S. flavoornata, S. nigriventris, and S. rachelae. These four species formed a clade with $S$. ignicolor $+S$. diminuta in two trees. A strict consensus of the six trees is given in Fig. 3a.

The successive weighting analysis yielded one tree, which is also one of the six original trees, with length $=80, \mathrm{CI}=0.8249$ (excluding uninformative characters $=0.7199$ ), $\mathrm{RI}=0.7641$, and $\mathrm{RC}=0.6303$ (Figs 3b, 4). Thirty-two characters had maximum weight $(=1.0)$ and 40 had lower weights. Twenty characters were parsimony-uninformative. Figure 4 gives bootstrap estimates (when > 50\%) and Bremer support indices for the clades recovered under equal weights. Apomorphies of this tree are given in Table 3.

The monophyly of Subrasaca was recovered in all most parsimonious trees (Fig. 3a). This clade, however, is not robust (bootstrap $<50 \%$, Bremer $=0$ ) (Fig. 4). Phylogenetically, Subrasaca can be tentatively defined by the following synapomorphic traits of its groundplan: (1) ocelli located slightly anterad of the imaginary line between the anterior angles of eyes (character 2, state 0; Fig. 1c), (2) complete transverse band on middle portion of crown (character 10, state 1), (3) triangular membranous area uniting subgenital plates basally (character 38, state 1; Fig. 1e), (4) obtuse shape of apex of styles in dorsal view (character 42, state 2), and (5) sclerites of female "inner" sternite VIII present (character 63, state 1; Fig. 2c-e).

Other phylogenetic (e.g., Felix and Mejdalani 2011) or purely taxonomic (e.g., Mejdalani et al. 2014) studies on the Cicadellini highlighted the need for more precise definitions of various genera of this tribe. In the introduction of his impressive monograph on the New World Cicadellini, Young (1977: 10) expressed his perception of this problem as follows: "The Cicadellini are an intricate group. Their morphology suggests rapid radiation and often shows small discontinuities compared with those found in many of the Proconiini." Small discontinuities are precisely what we have observed between Subrasaca and the genera here employed as outgroups. In any case, the cladistic analysis allowed us to propose a more objective definition of the genus.

Two clades appeared in all six most parsimonious trees and were fairly robust in the analysis (Fig. 4). The clade formed by the species with longitudinal dark brown 
a

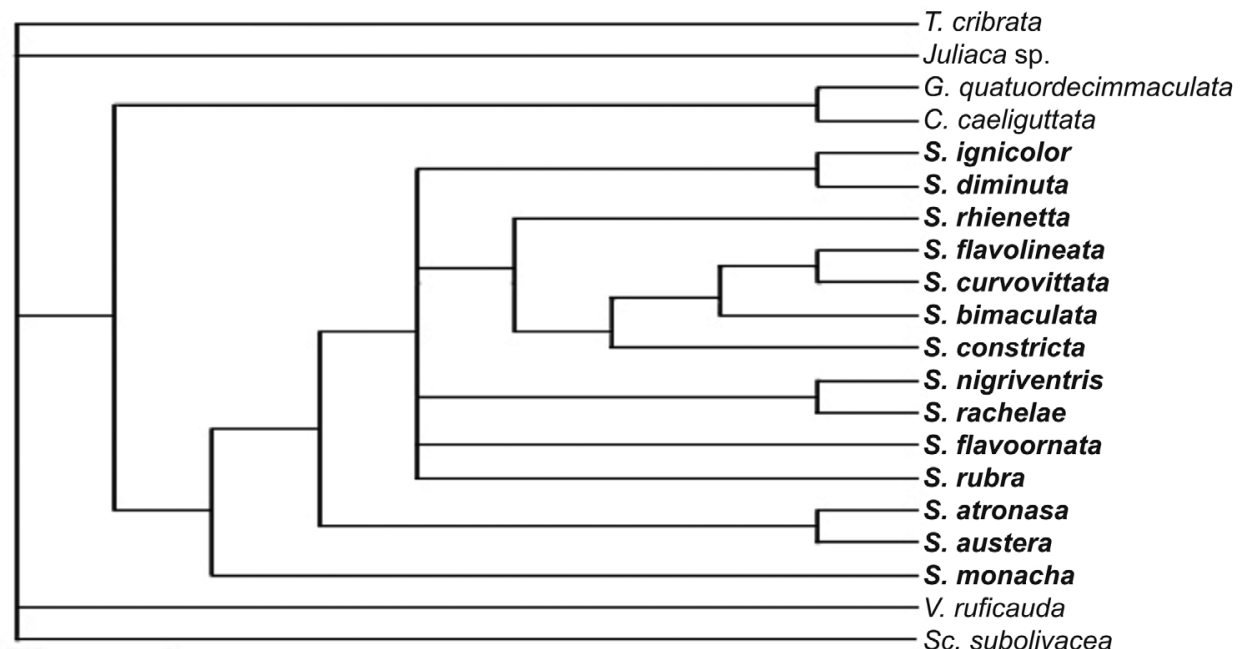

b

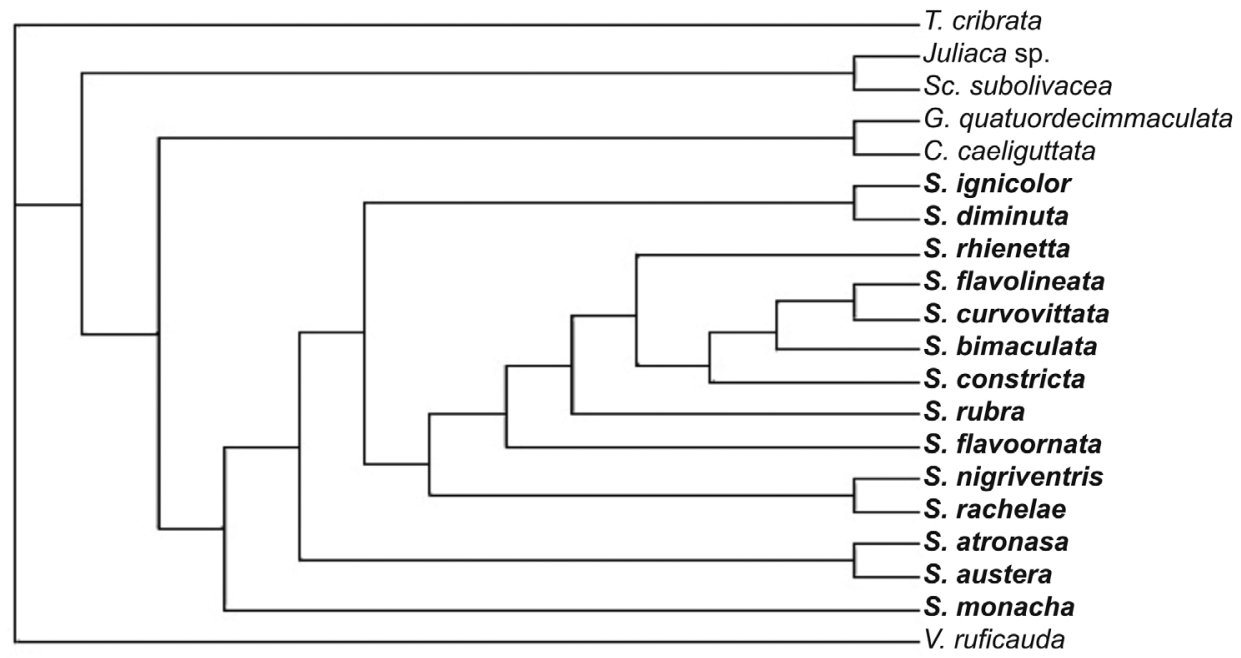

Figure 3. a Strict consensus of the six equally most parsimonious trees of the phylogenetic analysis of Subrasaca and outgroup taxa $\mathbf{b}$ Most parsimonious tree obtained with the successive weighting procedure; length $=80$, consistency index $=0.8249$ (excluding uninformative characters $=0.7199$ ), retention index $=0.7641$, rescaled consistency index $=0.6303$. Outgroup genera are Cyclogonia, Geitogonalia, Juliaca , Scopogonalia, Versigonalia, and Tretogonia (root).

to black stripes on the forewings (S. bimaculata, S. constricta, S. curvovittata, and $S$. flavolineata) had the highest percentage of bootstrap (=83\%) and was supported by seven apomorphic conditions (Table 3, node 26), including the conspicuous set of dark brown to black longitudinal stripes on the forewings (character 25, state 1; Fig. 1b, c). The Bremer support of this clade was 3. It shows the following internal 
Table 3. Apomorphy list for clades of Fig. 4 of the phylogenetic analysis of Subrasaca and outgroup taxa. Non-homoplastic characters are in bold.

\begin{tabular}{|c|c|}
\hline Node or terminal taxon & Apomorphies \\
\hline 37 & $37(0), 53(0), 54(1)$ \\
\hline 21 & 1(1), 22(6), 24(1), 65(1) \\
\hline 36 & $8(1), 40(1), \mathbf{6 4}(\mathbf{1})$ \\
\hline 22 & 5(2), 19(1), 44(2), 51(0), 61(1) \\
\hline 35 (Subrasaca) & $2(0), \mathbf{1 0}(1), 38(1), 42(2), 63(1)$ \\
\hline 34 & $46(1), 48(0)$ \\
\hline 33 & 1(1), 3(A), 5(3), 9(2), 14(1), 23(1), 33(1), 66(0), 72(1) \\
\hline 32 & $19(1), 22(0), 24(0)$ \\
\hline 23 & $3(5), 70(0)$ \\
\hline 31 & 21(2), 42(0) \\
\hline 30 & $6(1), 11(1), 62(1)$ \\
\hline 29 & 21(3), 51(1), 65(1), 66(4), 67(1) \\
\hline 28 & $8(0), 72(1)$ \\
\hline 27 & 1(1), 4(1), 7(1), 12(1), 13(1), 19(0), 47(1), 67(0) \\
\hline 26 & 16(1), 22(1), 24(1), 25(1), 28(1), 70(0), 72(0) \\
\hline 25 & 2(1), 3(8), 17(1), 47(0), 55(2), 59(1), 69(1) \\
\hline 24 & $42(1), 62(1)$ \\
\hline Versigonalia ruficauda & 3(B), 6(1), 13(1), 22(8), 24(4), 28(1), 30(2), 35(2), 71(1), 72(2) \\
\hline Juliaca sp. & 2(1), 12(1), 13(1), 18(1), 39(1), 61(3), 68(2), 69(1), 72(1) \\
\hline Scopogonalia subolivacea & $3(\mathrm{C}), 22(9), 37(1), 38(1), 42(0), 49(1), 63(1)$ \\
\hline G. quatuordecimmaculata & 2(1), 3(4), 4(1), 21(1), 22(0), 24(2), 35(1), 41(1), 43(0), 49(1), 61(2), 68(3) \\
\hline Cyclogonia caeliguttata & $9(2), 11(1), \mathbf{2 0}(2), 69(1)$ \\
\hline Subrasaca monacha & $3(2), 9(1), 49(1), 50(0), 51(3), 55(0)$ \\
\hline Subrasaca atronasa & $24(1), 32(1)$ \\
\hline Subrasaca austera & $4(1), 15(1)$ \\
\hline Subrasaca ignicolor & $3(6), 24(2), 41(1), 65(1)$ \\
\hline Subrasaca diminuta & $57(1)$ \\
\hline Subrasaca nigriventris & $46(0), 48(1), 49(1), 66(0), 70(0)$ \\
\hline Subrasaca rachelae & 22(3), 24(3), 45(0), 52(1), 60(1), 61(1) \\
\hline Subrasaca flavoornata & $3(9), 42(1), 44(0), 46(0), 48(1), 49(1), 60(1), 61(1)$ \\
\hline Subrasaca rubra & $3(0), 24(2), 35(1), 66(3), 71(1)$ \\
\hline Subrasaca rhienetta & $2(2), 3(3), 18(1), 32(1), 42(2), 62(1), 65(0)$ \\
\hline Subrasaca constricta & $4(0), 22(7), \mathbf{2 6}(\mathbf{2}), \mathbf{2 7}(\mathbf{1}), \mathbf{3 1}(\mathbf{1}), \mathbf{3 6}(\mathbf{1}), 45(0), 58(1), 66(0), \mathbf{6 8}(5)$ \\
\hline Subrasaca bimaculata & $22(4), \mathbf{2 6}(1), \mathbf{5 6}(\mathbf{1}, \mathbf{2}), 61(1), 63(0), \mathbf{6 8}(1)$ \\
\hline Subrasaca flavolineata & 5(1), 22(2), 41(1), 55(1), 58(1), 66(1) \\
\hline Subrasaca curvovittata & $3(7), \mathbf{2 9}(\mathbf{1}), 67(1), \mathbf{6 8}(\mathbf{6})$ \\
\hline
\end{tabular}

relationships in all trees (Fig. 3a): (S. constricta (S. bimaculata (S. flavolineata, S. curvovittata))). These four species were described in detail by Silva et al. (2013a). The group is distributed in the Atlantic Forest from northeastern (state of Bahia) 


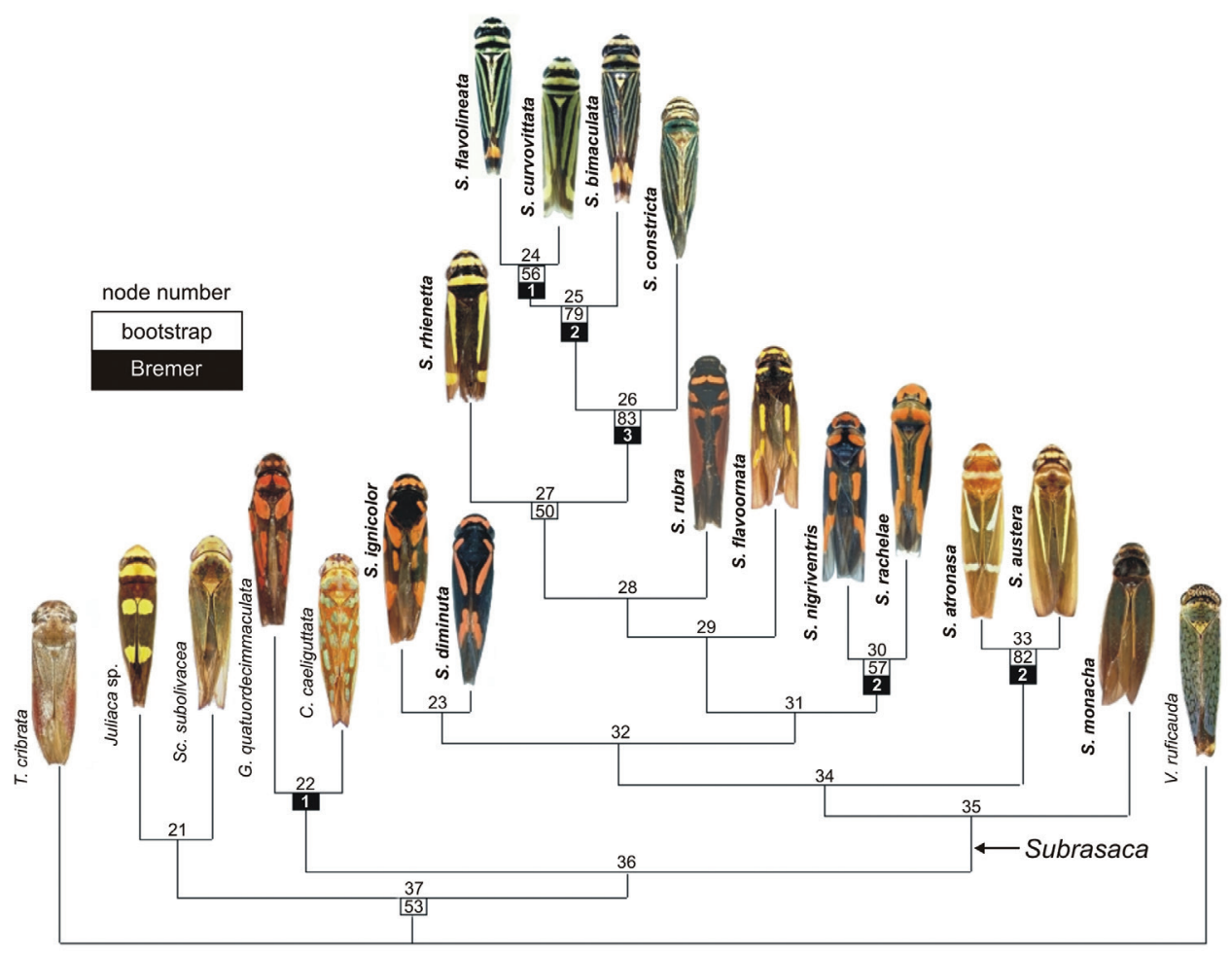

Figure 4. One of the most parsimonious trees of the phylogenetic analysis of Subrasaca and outgroup taxa; this is also the single tree obtained with the successive weighting procedure. Length $=197$, consistency index $=0.6091$ (excluding uninformative characters $=0.5389$ ), retention index $=0.5722$, rescaled consistency index $=0.3486$. Species of Subrasaca in bold. Apomorphies are given in Table 3. Most sharpshooter images from Wilson et al. (2009).

to southern Brazil (state of Paraná). The second clade, formed by $S$. atronasa $+S$. austera, is supported by nine apomorphic conditions (Table 3, node 33), including a whitish-yellow transverse band on middle portion of pronotum (character 14, state 1; Fig. 4, node 33). This clade also had relatively high bootstrap $(=82 \%)$ and Bremer $(=2)$ scores. These two species, which are known only from the state of Santa Catarina (Zanol and de Menezes 1982) in southern Brazil (Atlantic Forest), were described by Young (1977), who considered them "very close" to each other (Young 1977: 479).

Although with low support scores, the clades formed by $S$. ignicolor $+S$. diminuta and $S$. nigriventris $+S$. rachelae were recovered in all most parsimonious trees (Fig. 4 , nodes 23 and 30, respectively). Unlike the species with longitudinal dark brown to black stripes on the forewings (node 26), those with contrasting orange marks ( $S$. diminuta + S. ignicolor, $S$. nigriventris $+S$. rachelae, and S. rubra) did not form a monophyletic group in any of the six most parsimonious trees. 


\section{Acknowledgments}

Early drafts of the manuscript benefited from the useful comments of Alcimar Carvalho (MNRJ), Márcio Felix (Instituto Oswaldo Cruz), Rachel Carvalho (MNRJ), and Stuart McKamey (National Museum of Natural History, Washington, D.C.). Daniela Takiya (DZRJ) kindly allowed us to study specimens under her care. RSS received a fellowship from Coordenação de Aperfeiçoamento de Pessoal de Nível Superior (CAPES) in connection with her M.Sc. studies. RRC and GM have fellowships from Conselho Nacional de Desenvolvimento Científico e Tecnológico (CNPq, processes number 303127/2010-4 and 301391/2011-4). This study was supported in part by Fundação de Amparo à Pesquisa do Estado do Rio de Janeiro (FAPERJ) (grants number E-26/171.281/2006 to Márcia Couri - MNRJ and E-26/111.181/2011 to Nelson Ferreira-Jr - DZRJ).

\section{References}

Bremer K (1988) The limits of amino acid sequence data in angiosperm phylogenetic reconstruction. Evolution 42: 795-803. doi: 10.2307/2408870

Bremer K (1994) Branch support and tree stability. Cladistics 10: 295-304. doi: 10.1111/ j.1096-0031.1994.tb00179.x

Carpenter JM (1988) Choosing among multiple equally parsimonious cladograms. Cladistics 4: 291-296. doi: 10.1111/j.1096-0031.1988.tb00476.x

Carpenter JM (1994) Successive weighting, reliability and evidence. Cladistics 10: 215-220. doi: 10.1111/j.1096-0031.1994.tb00173.x

Cryan JR (2005) Molecular phylogeny of Cicadomorpha (Insecta: Hemiptera: Cicadoidea, Cercopoidea and Membracoidea): adding evidence to the controversy. Systematic Entomology 30: 563-574. doi: 10.1111/j.1365-3113.2004.00285.x

Dietrich CH (2005) Keys to the families of Cicadomorpha and subfamilies and tribes of Cicadellidae (Hemiptera: Auchenorrhyncha). Florida Entomologist 88: 502-517. doi: 10.1653/0015-4040(2005)88[502:KTTFOC]2.0.CO;2

Dietrich CH, Deitz LL (1993) Superfamily Membracoidea (Homoptera: Auchenorrhyncha). II. Cladistic analysis and conclusions. Systematic Entomology 18: 297-311. doi: 10.1111/ j.1365-3113.1993.tb00668.x

Dietrich CH, Rakitov RA, Holmes JL, Black WC (2001) Phylogeny of the major lineages of Membracoidea (Insecta: Hemiptera: Cicadomorpha) based on $28 \mathrm{~S}$ rDNA sequences. Molecular Phylogenetics and Evolution 18: 293-305. doi: 10.1006/mpev.2000.0873

Evans JW (1963) The phylogeny of the Homoptera. Annual Review of Entomology 8: 77-94. doi: 10.1146/annurev.en.08.010163.000453

Farris J (1969) A successive approximations approach to character weighting. Systematic Zoology 18: 374-385. doi: 10.2307/2412182

Farris J (1989) The retention index and the rescaled consistency index. Cladistics 5: 417-419. doi: 10.1111/j.1096-0031.1989.tb00573.x 
Felix ME, Mejdalani G (2011) Phylogenetic analysis of the leafhopper genus Apogonalia (Insecta: Hemiptera: Cicadellidae) and comments on the biogeography of the Caribbean islands. Zoological Journal of the Linnean Society 163: 548-570. doi: 10.1111/j.10963642.2011.00724.x

Felsenstein J (1985) Confidence limits on phylogenies: an approach using the bootstrap. Evolution 39: 783-791. doi: $10.2307 / 2408678$

Hamilton KGA (1981) Morphology and evolution of the rhynchotan head (Insecta: Hemiptera, Homoptera). Canadian Entomologist 113: 953-974. doi: 10.4039/Ent113953-11

Hamilton KGA (1983) Classification, morphology and phylogeny of the family Cicadellidae (Rhynchota, Homoptera). In: Knight WJ, Pant NC, Robertson TS, Wilson MR (Eds) Proceedings of the 1st International Workshop on Biotaxonomy, Classification and Biology of Leafhoppers and Planthoppers of Economic Importance, London, 4-7 October 1982. Commonwealth Institute of Entomology, London, 15-37.

Hamilton KGA (1999) The ground-dwelling leafhoppers Myerslopiidae, new family, and Sagmatiini, new tribe (Homoptera: Membracoidea). Invertebrate Taxonomy 13: 207-235. doi: $10.1071 /$ IT96028

Hill BG (1970) Comparative morphological study of selected higher categories of leafhoppers (Homoptera: Cicadellidae). Ph.D. dissertation, North Carolina State University, Raleigh. McKamey SH (2007) Taxonomic catalogue of the leafhoppers (Membracoidea). Part 1. Cicadellinae. Memoirs of the American Entomological Institute 78: 1-394.

Mejdalani G (1993) Morfologia da cabeça de Versigonalia ruficauda (Walker, 1851), com notas sobre a terminologia (Homoptera, Cicadellidae, Cicadellinae). Revista Brasileira de Entomologia 37: 279-288.

Mejdalani G (1998) Morfologia externa dos Cicadellinae (Homoptera, Cicadellidae): comparação entre Versigonalia ruficauda (Walker) (Cicadellini) e Tretogonia cribrata Melichar (Proconiini), com notas sobre outras espécies e análise da terminologia. Revista Brasileira de Zoologia 15: 451-544. doi: 10.1590/S0101-81751998000200015

Mejdalani G, Quintas V, Felix ME, Cavichioli RR (2014) A new species of Paratubana from the Atlantic Forest of Brazil and a key to males of the genus (Insecta: Hemiptera: Cicadellidae: Cicadellini). Studies on Neotropical Fauna and Environment 49: 127-134. doi: $10.1080 / 01650521.2014 .939450$

Nielson MW (1965) A revision of the genus Cuerna (Homoptera, Cicadellidae). Technical Bulletin of the United States Department of Agriculture 1318: 1-48.

Nielson MW (1985) Leafhopper systematics. In: Nault LR, Rodriguez JG (Eds) The leafhoppers and planthoppers. John Wiley and Sons, New York, 11-39.

Nixon KC, Carpenter JM (1993) On outgroups. Cladistics 9: 413-426. doi: 10.1111/j.10960031.1993.tb00234.x

Oman PW (1949) The Nearctic leafhoppers (Homoptera: Cicadellidae). A generic classification and check list. Memoirs of the Entomological Society of Washington 3: 1-253.

Oman PW, Knight WJ, Nielson MW (1990) Leafhoppers (Cicadellidae): a bibliography, generic check-list and index to the world literature 1956-1985. CAB International Institute of Entomology, Wallingford.

Page R (2001) NEXUS Data Editor, Version 0.5.0. 
Pinna MCC (1991) Concepts and tests of homology in the cladistic paradigm. Cladistics 7: 367-394. doi: 10.1111/j.1096-0031.1991.tb00045.x

Redak RA, Purcell AH, Lopes JRS, Blua MJ, Mizell RF, Andersen PC (2004) The biology of xylem fluid-feeding insect vectors of Xylella fastidiosa and their relation to disease epidemiology. Annual Review of Entomology 49: 243-270. doi: 10.1146/annurev. ento.49.061802.123403

Silva RS, Cavichioli RR, Mejdalani G (2013a) Descriptions of two new Brazilian Subrasaca species and redescriptions of $S$. flavolineata (Signoret, 1855) and S. curvovittata (Stål, 1862) comb. nov. (Hemiptera: Cicadellidae: Cicadellini). Zootaxa 3637: 450-461. doi: 10.11646/zootaxa.3637.4.4

Silva RS, Cavichioli RR, Mejdalani G (2013b) Descriptions of three new Brazilian Subrasaca species, redescription of $S$. nigriventris (Signoret, 1855) and a key to males of the genus (Hemiptera: Cicadellidae: Cicadellini). Zootaxa 3722: 372-384. doi: 10.11646/ zootaxa.3722.3.6

Sorenson MD, Franzosa EA (2007) TreeRot, version 3. Boston University, Boston.

Swofford DL (2002) PAUP*, Phylogenetic Analysis Using Parsimony (*and other methods). Version 4. Sinauer Associates, Sunderland.

Takiya DM (2007) Systematic studies on the leafhopper subfamily Cicadellinae (Hemiptera: Cicadellidae). Ph.D. dissertation, University of Illinois, Urbana.

Wilson MR, Turner JA, McKamey SH (2009) Sharpshooter leafhoppers of the world (Hemiptera: Cicadellidae subfamily Cicadellinae). National Museum Wales. http://naturalhistory. museumwales.ac.uk/sharpshooters/home.php [accessed 22 October 2014]

Yeates D (1992) Why remove autapomorphies? Cladistics 8: 387-389. doi: 10.1111/j.10960031.1992.tb00080.x

Young DA (1968) Taxonomic study of the Cicadellinae (Homoptera, Cicadellidae). Part 1, Proconiini. Bulletin of the United States National Museum 261: 1-287. doi: 10.5479/ si.03629236.261.1

Young DA (1977) Taxonomic study of the Cicadellinae (Homoptera: Cicadellidae). Part 2, New World Cicadellini and the genus Cicadella. Bulletin of North Carolina Agricultural Experiment Station 239: vi +1135 pp.

Young DA (1986) Taxonomic study of the Cicadellinae (Homoptera: Cicadellidae). Part 3. Old World Cicadellini. Bulletin of North Carolina Agricultural Experiment Station 281: 1-639.

Young DA, Beirne BP (1958) A taxonomic revision of the leafhopper genus Flexamia and a new related genus (Homoptera, Cicadellidae). Technical Bulletin of the United States Department of Agriculture 1173: 1-53.

Zanol KMR, de Menezes M (1982) Lista preliminar dos cicadelídeos (Homoptera, Cicadellidae) do Brasil. Iheringia (Série Zoologia) 61: 9-65. 